\title{
The Problem of Fatalism
}

\author{
By HELMER RINGGREN
}

It seems that the hardest task in the study of religion is to define its object, in other words, to determine what religion is. A new work in the history, psychology or sociology of religion almost inevitably begins with a new and original definition of the concept of religion. It is not my intention to add another definition to the number of those already existing. But I think it is possible to state on a purely empirical basis that one of the functions of what we normally call religion is to help man to adjust himself to the realities of life, to give him some kind of understanding of what happens to him, to enable him to relate himself in some way or other to what he regards as his destiny or fate.

Since in most languages the words for 'destiny' are rather ambiguous, it is necessary to make it clear from the outset what we mean when referring to a man's destiny. As has already emerged, there are two English words that should be taken into consideration, "destiny" and "fate". According to the Oxford dictionary, "destiny" means (I) That which is destined or fated to happen. (2) That which is destined to happen to a particular person, country, institution, etc.; (one's) appointed lot or fortune. (3) What in the course of events will become, or has become, of a person or thing. (4) The power or agency by which events are unalterably predetermined. The word 'fate' is analyzed as having approximately the same shades of meaning, although in a different order.

I should like to concentrate here on the second of the meanings listed, but I prefer to start from a somewhat broader concept with less emphasis on the element or predetermination. Things happen to man, they come upon him, so to speak, from the outside, and he has no power to change or to control them. It is to this part of his existence that man has to get into some kind of relationship, and the first step in this direction is an attempt to define what 
happens to him and to interpret it in a satisfactory way. It is here that the categories 'god', 'destiny', and 'chance' enter the scene, depending on whether the events are derived from a personal power, an impersonal order, or no order at all. We disregard, then, the pure scientific, causal explanation of the world.

If the power of destiny is regarded as impersonal, it is impossible to enter into any kind of relationship with it. The decree of destiny cannot be changed or averted and it is no use praying or offering sacrifices, for there is no one to hear or to receive and to react. On the other hand, if man's fate is decreed by a god, it is possible to enter into relationship with him, and sacrifices, prayer and obedience may be thought to avert an evil destiny or create a good one, and so forth. In other words, the belief in a personal determiner of destiny produces religious behaviour, while the belief in an impersonal Fate does not. But the problem is complicated by the fact that both of these attitudes seem to occur together in one and the same religion, even in one and the same person.

It is above all in the Greek and in the ancient Teutonic religions that the problem of the relation between the gods and Destiny becomes acute, and students in these fields were aware of it long ago and paid due attention to it. The first to carry out a more comprehensive investigation of the ideas of destiny in various religions seems to have been E. Engel who wrote Die Schicksalsidee im Altertum in 1926. But this is a rather superficial work, based for the most part on secondary evidence, and does not reach the core of the matter. Some special investigations concerning particular religions supply valuable details of information but, as a rule, do not touch upon the problem under discussion here.

Some recent works by Swedish scholars were, directly or indirectly, influenced by J. B. Pratt's definition of religion as people's "attitude toward the power or powers which they conceive as having ultimate control over their interests and destinies". ${ }^{1}$ This definition was taken up by $\mathrm{Hj}$. Sundén in his dissertation on Bergson's theory of religion (1940), ${ }^{2}$ and by Widengren in

1 J. B. Pratt, The religious consciousness, New York I920, p. 2.

${ }_{2} \mathrm{Hj}$. Sundén, La théorie Bergsonienne de la religion, Uppsala I940, passim. See e.g. p. 203: "... la vraie définition de la religion: la religion est une explication de la détermination de la destinée humaine." Cf. also p. ${ }_{53} \mathrm{f}$. 
Religionens värld (1945). ${ }^{1}$ In the last mentioned work, Widengren also points out that Pratt's definition, and especially his term 'Determiner of Destiny' applies remarkably well to a particular form of theism (this term will be used here for any belief in a god, or gods), namely the idea of the so-called high god. Thus Widengren's Hochgottglaube im alten Iran (1938) also comes into the picture. In this book Widengren, on the basis of African and Iranian evidence, wanted to show that the idea of a sky-god, who is the Determiner of Destiny responsible both for good and evil, is an original phenomenon which cannot be understood as a late development or as a result of Christian missions. Pratt is not mentioned in Hochgottglaube, but some statements in Religionens värld show that this combination is not alien to Widengren's thinking. ${ }^{2}$ It seems to me, however, that there is a slight change of emphasis from Pratt's 'interests and destinies' to Widengren's 'destiny' or 'Schicksal'. Pratt's term is broader, as indicated already by the plural form, 'destinies' and, in addition, includes the more active term 'interest'.

Widengren thinks that the idea of god is primary in religion and does not derive from anything else (such as the idea of mana, or supernatural power, the belief in spirits, etc.). But then it would follow that the religious interpretation of destiny as decreed by a personal god is also primary and that all instances of an impersonal Fate that exists independently of the gods or even stands above them, represent a later development, which may be described as a hypostatization of a function of the god, or gods. This view seems to be present behind Ugo Bianchi's work on the idea of destiny in Homer (Dios aisa, 1953). For here the main emphasis is placed on the fact that destiny is the decree of Zeus, and the writer makes every effort to explain away all passages in which destiny seems to be independent of Zeus so as to strengthen his main thesis. According to this view, it was only considerably later that the Greeks separated destiny from Zeus and finally came to regard it as a power that was even stronger than the gods.

It is not difficult to proceed beyond this point to the idea that theistic religion originated in man's reaction to destiny, attributing it to a personal being, or 'high god'. This view is actually defended by Sundén in his book

1 G. Widengren, Religionens värld, and ed., Stockholm I953, pp. Io f.

2 E.g. p. Ir: "Vi skola se att denna definition särskilt väl passar in på den typ av gudstro, höggudstron ..." Cf. also pp. $58 \mathrm{f}$., $68 \mathrm{f}$. 
Gud, odet, slumpen (I947). According to him it is man's reaction to that which happens to him that forms the very kernel of the religious experience: he feels dependent, powerless, guided; he seeks, and finds perhaps a purpose or a meaning behind the events-or he finds no meaning at all. If he conceives of the power behind the events as personal, the result is a god, if not, it is Fate or chance. Sundén thinks that the ability to ascribe a meaning or a purpose to events is universal and that it constitutes what he, following Andræ, 1 calls the religious disposition (Anlage). G. Klingberg in his Studier $i$ barnens religiösa liv (1953) applies the same theory on evidence drawn from the religious life of school children.

Prof. E. Ehnmark of Lund has also given some attention to the theoretical problem of fatalism, or perhaps rather of destiny, in his dissertation on The Idea of God in Homer (1935), and in his popular book Världsreligionerna (1955). According to him, belief in destiny and belief in $\operatorname{god}(\mathrm{s})$ (or, religion) are two basically different and incompatible attitudes. "It is typical of destiny that it is conceived of as something given, as an order of things. Destiny is understood as something natural, as 'the way of the world'. That which is one's destiny is the normal, that which follows from the nature of things and life as they happen to be". It is no use complaining about destiny, for there is nobody to listen, "for destiny is not a power that governs, but an order that exists." When it is said, "nobody dies until his time has come" or that somebody "has lived out his time", this does not mean that the hour of death has been fixed by some power, but "only that the general conditions of life are such that every man has a certain life span allotted to him".2

One might ask if the order factor is not somewhat exaggerated in this argument. At any rate, it does not seem to fit in with certain comcrete manifestations of fatalism (i.e. belief in fate). It is often not only its inexorableness, but also its capriciousness that gives destiny its character.

From a theoretical point of view Ehnmark's distinction may be of significance. But like the distinction between religion and magic it is sometimes hard to apply in practice. In reality theism and fatalism are intertwined, and there is in the realm of religion a great variety of interpretations of destiny in

1 T. Andræ, Die Frage der religiösen Anlage, Uppsala r932.

2 E. Ehnmark, Världsreligionerna, 2nd ed., Stockholm I96I, p. I 9. 
the sense of that which happens to man, the predetermined lot, the inescapable. 'The 'fatalism' of Islam is strictly speaking not a belief in destiny but presupposes the predetermination of the almighty God. The Persian national epic Shähnämah at times refers to destiny as some kind of moral retribution. And, as already hinted at, in Homer, aisa and moira as a rule denote things allotted by Zeus. The Indians often call destiny daivam, i,e. the divine, the godsent, but at the same time, they regard it as the result of karma, the deeds performed in a previous existence.

Ehnmark is aware of this. He writes, "From a psychological point of view the difference between fatalism and theism is one of outlook. Therefore, the same man can have both opinions, although, of course, not with reference to the same event. At one time he says perhaps, 'this was my destiny', at another 'it was God's will'". 1

The first thing to be done in order to clarify these questions, it seems to $\mathrm{me}$, is to ascertain what, in each case or in each milieu, is meant by 'destiny'. The concept is by no means clear and unambiguous, and further complication arises from the fact that some languages have several words for 'destiny'. It is necessary, then, to examine linguistic usage very carefully.

It turns out that, in spite of rich variation, there are certain characteristic ways of expression that are common to several cultures. The preislamic Arabs as well as ancient Teutons had a certain preference for passive verbal forms in order to express the predetermined lot: "it was destined for him", "it was allotted to him", or simply the impersonal form "it became (was)". ${ }^{2}$ Especially in the case of Arabic is it important to bear in mind that the passive form in itself implies that the allotter is not defined: the Arabic passive form does not take an agent. The Persian phrase büdandah büd, "what was to be, was (i.e. happened)", which is very common in the Shähnāmah, expresses the same idea combined with that of the inexorable necessity of fate. ${ }^{3}$

To the same group of words for 'destiny' we might perhaps reckon the passive participles that denote destiny as that which is 'destined', 'decreed',

1 Ib, p. 22.

2 H. Ringgren, Studies in Arabian Fatalism, Uppsala 1955, p. 7; id., Foumal de Psychologie 53, 1956, p. 410, with reference to Gehl, Der germanische Schicksalsglaube, Berlin r939, p. 39 .

3 E.g. H. Ringgren, Fatalism in Persian epics, Uppsala 1952, p. I6 (note 6), p. $5^{8}$ (note 9), p. 62 (note I3). 
'allotted', or 'sent', as e.g. fatum, "(that which is) said, decreed"; heimarmene, "(that which is) allotted"; the old Swedish audhinn $>$ mod. Swedish öde; certain Indian words. But it is often difficult to see the difference between a simple noun formed from the same root and such a participle. Is it possible to maintain a clear distinction between the Greek moira and heimarmenē, (both from the same root), or to say why Arabic uses maniyah, allotment (i.e. death) rather than a participle? Other such words are Icel. skqp, Ags. giscapu (the allotted), German Schicksal, Geschick (schicken = to send).

Words meaning 'lot' or 'share' are rather common. But do they not presuppose somebody who allots or distributes? In Persian there is a word bakht, 'fortune', from Pahl. bakht, 'something allotted', but in the oldest texts there is also a bagha, as a divine epithet, the Allotter, and baghöbakht is 'that which has been allotted by the Allotter'. 'The modern Persian word connotes personified fortune or luck, in some respects comparable to the Nordic hamingja and fylgja. Among the Indian terms for destiny we find bhagadeyam, 'god-given lot', and, as we saw, daivam, '(something) divine' or 'determined by god(s)'.

In a fairly well defined area, words for 'time' have come to be used to denote destiny. This is true of Iranian religion - where Time even appears as a god, Zervan, but also in a more general sense in the epics-in India, where $k a \overline{l a}$ is 'destroying time', in preislamic Arabia, and to some extent in Israel.2 This usage has two aspects. On the one hand, time is equal to time with its contents, i.e. the events that take place within time, and in this connection certain Pahlavi writings present philosophical speculations on time and space as prerequisites for all that happens. When the O.T. writer says, "my time is in thine hands", he means not only time in itself or the lifetime of man, but all that is contained in his lifetime, i.e. his destiny. On the other hand, time is the destroying factor, the power of destruction: "nothing resists time, not even the firm mountains", says an Arabic poet; consequently death and destruction are the inescapable lot or destiny of man. The inexorable course of time serves as a symbol for the inescapability of fate.

There are also words that emphasize the course of events: destiny is

1 Ringgren, Fatalism in Persian epics pp. $9 \circ \mathrm{f}$, with reference to G. Widengren, Hochgottglaube im alten Iran, Uppsala 1938, pp. $377 \mathrm{ff}$.

2 Ringgren, Fatalism in Persian epics pp. $35 \mathrm{ff}$. 
chance. Greek tychē belongs to this category; for tynchanō means 'to happen by chance'.

However, there is a risk in placing too much emphasis on etymologies and so-called original meanings. The significance of etymology has been exaggerated both in comparative religion and in Biblical research, and James Barr's criticism in The Semantics of Biblical language (196I) is applicable also to much that has been done in the field of the history of religions. It is the actual use of words in the textual connection we are studying that is important, not what the words meant "originally", but what they mean in the present linguistic or cultural context. Used with caution and common sense, etymologies can provide us with certain historical evidence, inform us about the previous history of an expression, but if the "original" meaning is applied to a much later context, the result is likely to be a distorted picture.

As applied to our present problem, this means that we should not base our argument too much on the original, etymological meaning of the words for 'destiny', but concentrate on the elucidation of the ideas and beliefs that are connected with fatalism, the attitudes it produces, etc. A good example is provided by the use of the ancient Arabic words for 'fate' in early Islamic poetry. Used in a new context, the words acquire a new and different meaning. Furthermore, it often turns out that several words are used to denote more or less the same thing; then it is not the word that is important, but the thing, in this particular case the idea of destiny.

In the light of this there are above all two sets of problems that come to the fore: I) How is what happens understood and defined, and how is it related to theistic beliefs, if there are any? and 2) How do people behave, and what attitude do they take toward that which is understood as destiny?

As to our first question, Bleeker has tried, in Numen vol. 2,1 to outline five different types of what he calls reaction to destiny-like events.

I. The universal insight that the wheel of fortune turns arbitrarily. One is a Sunday-child, the other is an unlucky fellow. Fortune and misfortune alternate in life without any visible ground or reason. Experiences of this kind do not always crystallize in a consistent doctrine. Often the result remains

1 C. J. Bleeker, "Die Idee des Schicksals in der altägyptischen Religion", Numen 2, 1955, pp. $28 \mathrm{ff}$., reprinted in $i d$., The sacred bridge, Leiden 1963, pp. I I $2 \mathrm{ff}$. The typology quoted is found on pp. $3 \mathrm{I}$ ff. and II4 ff. respectively. 
empirical wisdom of life with a religious colouring: you must accept adversities and remain calm when unexpected luck comes; for there are, after all, forces you cannot influence or change.

2. The idea that a man's destiny is in some way linked with his birth. Tales are told about fairies who give the new-born child all kinds of good things, or about evil spirits, witches or magicians who determine for it misfortune in some form or other. In a more systematic form this idea is found in astrology: it is the position of the stars at man's birth that determines his destiny. In addition, Hellenistic astrology, at least, was anchored in a comprehensive doctrine of universal cosmic laws and of correspondence between celestial and earthly phenomena.

3. The ancient idea of a world-order, which is inscrutable but reliable: all events are subject to this order, which will finally be realized in good as well as in bad men. This is basically an optimistic attitude. Examples include Indian $r t a$, Chinese tao, Egyptian $m a^{\prime} a t$, and Greek themis, which, according to $\mathrm{K}$. Lehr is the divine order that the Moiras follow in determining the destinies which are then sanctioned by Zeus, heimarmenë, anankë, Dike, Nemesis and the Erinyes. The karma of Hinduism and Buddhism belongs here, too, at least to some degree: an inexorable law of causality makes every action create results which appear as destiny in a subsequent existence.

4. The pessimistic conviction that man is subject to a mostly unhappy fate which he cannot escape. In Greek tragedy we find people with a curse resting upon them who in spite of their best intentions are entangled in guilt, who are driven by overwhelming forces till they, although innocent, appear guilty. and can assert their dignity only by devoting themselves to destruction. Bleeker finds something of this idea also in ancient Nordic religion, especially in the myths of Balder's death and Ragnarök. The theme is here intensified to the level of heroic defiance: the Islandic sagas relate how the warriors undauntedly meet fate(death), when their 'fortune' has abandoned them. Similar ideas are also found in preislamic Arab poetry.

5. The belief that an omnipotent god with supreme power determines, or has even determined in advance, man's destiny, both good and ill fortune, both salvation and eternal damnation. This idea is possible only in monotheistic religions or religions in which lesser gods are at least not able to interfere in the course of world events as predetermined by the supreme god. 
Bleeker refers to Calvin's doctrine of predestination and the religious 'fatalism' of Islam, which even if they differ in content are similar in structure. He says, "However, in both cases, this belief is burdened with a problem that constantly repeats itself: the human drive to freedom revolts against a purely deterministic conception of God, and where trust in divine providence is predominant, the realisation of evil destiny is a constant cause of disturbance".

It seems to me that this classification does more justice to the actual manifoldness of these ideas that Ehnmark's strict distinction between two alternatives: fate-god. Nevertheless, the relation between fatalism and theism remains one of the most important problems we have to face. I am not so much concerned, then, about the question of priority: which one was there first, fatalism or theism? Rather, our task concerns the interrelationship between the two in the religions actually existent, and perhaps ultimately envisages the use of possible results for a definition of the essence of religion. Here we meet with questions like these: Is destiny that which God, or the gods, determine, or is it something that is more or less independent of the divine will, a power on which even the gods are dependent? Both opinions existand it is perhaps not worthwhile to ask which one of them was absolutely first, but in some cases, e.g. in Greece, it is possible to follow the course of development for some centuries. How is impersonal fate related to a personal god? How is it possible that these two ideas can exist side by side? Is it an example of the general lack of logic that is often met with in religion, as, for instance, when Christian preaching sometimes says that the deceased have gone to their home in heaven and sometimes speaks of resurrection and the last judgment? Is it an instance of the phenomenon that Hultkrantz has called attention to in his interesting paper on 'Configurations of religious beliefs'. 1 In other words, are there certain situations, certain contexts in which fatalism is actualized, and others in which theism naturally appears? If so, what are they?

The second main question concerns the attitude to take toward destiny. What does man do, or what should he do, when he is hit by that which is destined? To what extent is destiny contingent upon his own doings? This

\footnotetext{
1 Published in Ethnos 1956 pp. $194 \mathrm{ff}$.
} 
last question is not as absurd as it might sound. It is a fact that Babylonian religion reckons with a destiny, šimtu, fixed by the gods. But there is a phrase saying that a man "died on a day that was not that of his destiny". ${ }^{1}$ Consequently, destiny is not unalterable. The question is: why and how is the predestined fate changed so that a man dies too early? Is it a punishment for sin, or something else? If it were not so often expressly stated that it is the gods who "determine the destinies", one might be tempted to use Ehnmark's category of an order: an untimely death is a death at an abnormal time, it breaks the order. But the texts are not explicit on that point.

Just as in Christianity and in Islam the relation between predestination and man's own work has been discussed, there are also in India discussions of the relations between destiny (devine decree) and human activity. Kautilya, a politician living about 300 B.C. states that human activity and destiny together rule the course of the world. Man's activity is wise or unwise, destiny is reflected in good and bad fortune. In the section of Matsyapurāna that is called Rajadharma and deals with the duties of the king, it is asked whether destiny or human activity is more valuable. The answer is that destiny, i.e. the karman of a persons earlier existence, has not the same value as action. Good action can reverse an adverse fate, and not even good karman will be realized without human activity. Only those who lack energy refer to destiny. The opinion is expressed that success is determined by three factors: destiny, activity and time. ${ }^{2}$

The question of man's attitude toward destiny has never, as far as I know, been treated systematically. I permit myself to quote, as a basis for our discussion, some sentences from a paper by a German colleague, ${ }^{3}$ which, unfortunately, is available only in a private edition. He mentions four basic interpretations of destiny, namely:

r. First, what he calls the primitive interpretation, which "derives all that happens to us, all that we experience in the world, from the caprice of mysterious, for the most part hostile and malicious gods, demons, or powers and

1 For šimtu, see C. Fichtner-Jeremias, "Der Schicksalsglaube bei den Babyloniern" (MVAG I922, 2), M. David, Les dieux et le destin en Babylonie, Paris 1949; and the remarks by A. L. Oppenheim, Ancient Mesopotamia, Chicago 1964, pp. $20 \mathrm{Iff}$.

2 H. Losch, Rājadharma, Bonn I959, pp, Io3 f.

a Fr. Maass, Professor of Old Testament exegesis at the university of Kiel. 
thinks that these powers can be placated by sacrifices or escaped in some way." To this view no meaning or purpose is found in destiny.

2. The heroic view of destiny believes in an inflexible law and an inescapable predetermination in world history. This interpretation occurs when the tragic hero comes to appear guilty or has to face destruction. He cannot do anything against destiny, but he can remain constant and thus vindicate himself. (This category is more or less identical with Bleeker, No. 4.)

3. Destiny can be denied or rejected. Man will not let the outward happenings, be they ever so terrible or painful, move or shake his mind. $\mathrm{He}$ tries to exclude the possibility of a real interference of destiny in his life, to screen himself off from destiny and to bear it calmly and indifferently. (This is more or less the attitude of ancient Arab poetry-s $a b r$, patience in the face of the strokes of destiny is the ideal. In stoicism this attitude concerns a destiny that is not really denied, but accepted as a manifestation of the rational order of the world.)

4. The acceptance of destiny, which the writer thinks to be especially characteristic of Christianity, but, as a matter of fact, is found wherever destiny is derived from the will of a god and, therefore, is supposed to have a meaning even if this meaning is sometimes, or perhaps even in most cases, hidden to the individual.

It is only the first of these types that needs further comment. It sums up too much under one heading. The gods are not always malicious. The destiny they decree is not always capricious and meaningless-this is more true of an independent and impersonal fate-and it is not at all certain that destiny can be escaped or avoided by sacrifices or otherwise. There are few concrete manifestations of so-called fatalism that do not contain traits from the other types.

It is not my intention to anticipate the discussions that will be pursued here. I have only tried to sketch some of the problems that seem important to me. It is obvious that some of the classifications proposed are not entirely satisfactory. It seems that whatever basis we choose for our classification, there will always be some phenomena that do not fit neatly into the pattern.

For my own part, I should like to start from man's attempt to adjust himself to his existence, to understand and define it and to arrange his life accordingly. We are dealing with the interpretation of that which happens. $2-654218$ Ringgren 
From one point of view the alternatives God, fate, and chance overlap in a series of transitional and blended forms. From another point of view, there is a whole spectrum of beliefs, ranging from the feeling of total dependence to the proud conviction that man is the architect of his own fortune. And from a third angle there are the attitudes of heroic defiance, pessimistic resignation and positive acceptance. The interrelation of fatalism with other aspects of man's way of looking at life as a whole is an interesting subject for research from each one of these angles. 